\title{
Nutritional status and fruit production of Carica papaya as a function of coated and conventional urea
}

\author{
Gabriel B. da Silva Júnior ${ }^{1}$, Eduardo M. dos Santos ${ }^{2}$, Roberto L. Silva ${ }^{3}$ \& Ítalo H. L. Cavalcante ${ }^{4}$ \\ ${ }^{1}$ Universidade Federal do Piauí/Centro de Ciências Agrárias/Departamento de Fitotecnia. Teresina, PI. E-mail: gabriel10barbosa@hotmail.com \\ ${ }^{2}$ Universidade Federal do Ceará. Fortaleza, CE. E-mail: eduardomagsantos@yahoo.com.br \\ ${ }^{3}$ Universidade Federal de Viçosa/Departamento de Solos. Viçosa, MG. E-mail: robertolustosa88@gmail.com \\ ${ }^{4}$ Universidade Federal do Vale do São Francisco/Colegiado de Engenharia Agronômica. Petrolina, PE. E-mail: italo.cavalcante@univasf.edu.br \\ (Corresponding author)
}

\section{Key words:}

Carica papaya L. controlled release fertilizer plant nutrition fruit yield

\begin{abstract}
A B S T R A C T
As a strategy to minimize $\mathrm{N}$ losses in the soil, mineral $\mathrm{N}$ sources, such as polymer-coated urea, have been studied as possibility to increase the synchronization of $\mathrm{N}$ release by the fertilizer and its absorption by plants. Thus, this study aimed to evaluate the contents of macronutrients and the production of Formosa papaya as a function of sources and doses of $\mathrm{N}$ fertilizer applied as top-dressing in the region of Bom Jesus-PI, Brazil. The treatments were arranged in a $2 \times 4$ factorial scheme corresponding to $\mathrm{N}$ sources (coated urea and conventional urea) and $\mathrm{N}$ doses $\left(350,440,530\right.$ and 620 g plant $^{-1}$ of $\mathrm{N}$ ), with four replicates and four plants per plot. The contents of macronutrients in the leaf dry matter and fruit production were evaluated. The sources and doses of top-dressing $\mathrm{N}$ fertilization incremented the leaf contents of macronutrients and the production of Formosa papaya hybrid Caliman 01. Under the experimental conditions and based on the macronutrient contents considered as adequate for crop nutrition, associated with maximum fruit production $\left(8.08 \mathrm{~kg} \mathrm{plant}^{-1}\right)$, the supply of $525 \mathrm{~g}$ of $\mathrm{N}_{\text {plant }}{ }^{-1}$ is recommended in the form of coated urea.
\end{abstract}

\author{
Palavras-chave: \\ Carica papaya L. \\ fertilizante de liberação lenta \\ nutrição de plantas \\ produtividade
}

\section{Estado nutricional e produção do mamoeiro Formosa em função da aplicação de ureia protegida e convencional}

\section{R E S U M O}

Como estratégia para minimizar as perdas de $\mathrm{N}$ no solo tem-se estudado fontes minerais de $\mathrm{N}$-fertilizantes protegidas com polímeros a partir das quais é possível aumentar o sincronismo entre a liberação do nutriente pelo fertilizante e sua absorção pela planta. Neste sentido teve-se, como objetivo, avaliar os teores dos macronutrientes e a produção do mamoeiro Formosa em função de fontes e doses de $\mathrm{N}$-fertilizante aplicadas em cobertura na região de Bom Jesus, PI. Os tratamentos foram dispostos em esquema fatorial $2 \times 4$ correspondentes a fontes de nitrogênio (ureia protegida e ureia convencional) e doses de nitrogênio (350, 440, 530 e $620 \mathrm{~g} \mathrm{planta}^{-1} \mathrm{de}$ N) com quatro repetições e quatro plantas por parcela. Avaliaram-se os teores de macronutrientes na massa seca foliar e a produção de frutos. As fontes e doses de adubação nitrogenada em cobertura incrementam as concentrações foliares de macronutrientes e a produção do mamoeiro Formosa híbrido Caliman 01. Nas condições em que o experimento foi desenvolvido e considerando os teores de macronutrientes admitidos como adequados para a nutrição da cultura associada à produção máxima de frutos $\left(8,08 \mathrm{~kg} \mathrm{planta}^{-1}\right)$ recomenda-se o fornecimento de $525 \mathrm{~g} \mathrm{planta}^{-1} \mathrm{de} \mathrm{N}$ na forma de ureia protegida. 


\section{INTRODUCTION}

Formosa papaya is a plant that absorbs large amounts of nutrients and has continuous requirements, especially during its first year, reaching the maximum point twelve months after transplantation (Fontes et al., 2010). The characteristics of intermittent harvest of papaya causes the plant to require water and nutrient supplies in frequent intervals, thus allowing the continuous flow of flower and fruit production (Brito Neto et al., 2011).

Despite the nutritional requirement of the crop, it is notorious the necessity to provide correct quantity of fertilizer in order to promote maximum plant yield (Santos et al., 2014). The recommendations of nitrogen $(\mathrm{N})$ fertilization for the crop vary considerably from region to region, in both the applied amount of nutrients and fertilization installments, which is due to the different ecological systems that directly influence fertilization efficiency.

Incorrect fertilizer management with respect to the dose, source and application frequency, has direct impact on plant nutrition, an essential factor for the achievement of economically viable productions. Thus, a nutritional balance must be promoted, especially regarding $\mathrm{N}$, since it has great importance in plant nutrition and participates as a constituent in proteins, nucleic acids and chlorophyll molecule, besides directly acting on the processes of cell division and expansion (Marchner, 2005). On the other hand, $\mathrm{N}$ fertilization management is complex, because of the multiplicity of soil biochemical reactions, dependence on edaphoclimatic conditions and vulnerability to losses in the soil (Hu et al., 2012).

Excessive application of $\mathrm{N}$ fertilizers can cause nutritional imbalance in the plants and pollute the environment through the contamination of the water table, which makes the practice of fertilization uneconomic, because there may be higher concentration of soluble forms of $\mathrm{N}$ in the soil solution, which are more susceptible to losses (Lorenzini et al., 2012). Therefore, as a strategy to minimize the availability of nitrate $\left(\mathrm{N}-\mathrm{NO}_{3}^{-}\right)$through leaching in the soil profile and ammonia (N$\mathrm{NH}_{3}$ ) through volatilization, mineral sources with controlled $\mathrm{N}$ release, such as polymer-coated urea, have been used, from which it is possible to increase the synchronization between $\mathrm{N}$ release from the fertilizer and its absorption by plants, compared with the use of conventional urea (Azevedo et al., 2009). According to Morgan et al. (2009), urea granules are coated with three layers of polymers and the outmost layer comprises a low-solubility additive, which requires a greater volume of water to dissolve (10 to $20 \mathrm{~mm}$ ), while the other layers remain in the solution along with ammonium $\left(\mathrm{NH}_{4}^{+}\right)$, thus compromising their recognition by nitrifying bacteria and reducing losses through leaching.

Currently, studies on the use of controlled-release fertilizers in the cultivation of fruit crops have been expanded in order to reduce the number of fertilizations per cycle and the final production cost (Kandil et al., 2010).

Therefore, this study aimed to evaluate the contents of macronutrients and the production of Formosa papaya as a function of sources and doses of $\mathrm{N}$ fertilizer applied as topdressing in the region of Bom Jesus-PI, Brazil.

\section{Material and Methods}

The experiment was carried out from November 2011 to February 2013, at the Fruticulture Experimental Area of the Campus Professora Cinobelina Elvas (CPCE), at the Federal University of Piauí (UFPI), in Bom Jesus-PI, Brazil (09 04' $28^{\prime \prime}$ S; 44 21' 31" W; $277 \mathrm{~m}$ ). The municipality of Bom Jesus belongs to the semiarid region of Piauí and has hot and humid climate, Cwa, according to Köppen's classification.

The seedlings were produced using certified seeds of Formosa papaya, hybrid Caliman 01 , provided by the Capixaba Institute of Research, Technical Assistance and Rural Extension (INCAPER). The substrates consisted of sandy soil and cattle manure at the proportion of $3: 1$, respectively, mixed with $1.4 \mathrm{~kg}$ of single superphosphate $\left(18 \%\right.$ of $\left.\mathrm{P}_{2} \mathrm{O}_{5}\right)$ and $1.0 \mathrm{~kg}$ potassium chloride $\left(60 \%\right.$ of $\left.\mathrm{K}_{2} \mathrm{O}\right)$ per $\mathrm{m}^{3}$ of substrate, following the recommendations of Marin (2004). The seedlings were transplanted when they were approximately $20 \mathrm{~cm}$ high, 60 days after sowing (Marin, 2004).

The treatments were arranged in a $2 \times 4$ factorial, corresponding to two $\mathrm{N}$ sources [coated urea (Kimcoat $\mathrm{N}^{\circ}$ ), covered with polymer layers and conventional urea, $45 \%$ of $\mathrm{N}$ ] and four $\mathrm{N}$ doses (350, 440,530 and 620 g plant $^{-1}$ of N). The treatments were distributed in randomized blocks with 4 replicates and 6 hermaphrodite plants of Formosa papaya per plot, 4 evaluated plants and 2 border plants, cultivated at double spacing ( $3.8 \mathrm{~m}$ between double rows $\mathrm{x} 1.8 \mathrm{~m}$ between rows $\mathrm{x} 2.0 \mathrm{~m}$ between plants), totaling 192 plants with a density of 1,785 plants ha ${ }^{-1}$.

$\mathrm{N}$ doses corresponded to $80,100,120$ and $140 \%$ of $\mathrm{N}$ fertilization, monthly divided, in a total of twelve applications, following the recommendations of Costa \& Costa (2007).

Potassium chloride $\left(60 \%\right.$ of $\left.\mathrm{K}_{2} \mathrm{O}\right)$ was used as $\mathrm{K}$ source, whereas single superphosphate $\left(18 \%\right.$ of $\left.\mathrm{P}_{2} \mathrm{O}_{5}\right)$ was used as $\mathrm{P}$ source. All the fertilizers (urea, single superphosphate and potassium chloride) were applied in a circle under the canopy projection, $20 \mathrm{~cm}$ distant from the stem and gradually incorporated to the soil.

The soil of the experimental area is classified as Quartzarenic Neosol (EMBRAPA, 2013) with sandy texture and showed the following physical and chemical characteristics before the experiment (Table 1).

The data referring to the climatic variables (temperature, relative air humidity and rainfall), collected at the weather

Table 1. Physical and chemical characteristics of the soil in the experimental area in the layers of 0-20 and 20-40 cm

\begin{tabular}{|c|c|c|c|}
\hline \multirow{2}{*}{$\begin{array}{c}\text { Soil } \\
\text { characteristics }\end{array}$} & \multirow{2}{*}{ Unit } & \multicolumn{2}{|c|}{ Layer (cm) } \\
\hline & & $0-20$ & $20-40$ \\
\hline $\mathrm{pH}-\mathrm{H}_{2} \mathrm{O}(1: 2.5)$ & - & 5.0 & 4.8 \\
\hline Potassium & $\mathrm{cmol}_{\mathrm{c}} \mathrm{dm}^{-3}$ & 0.23 & 0.11 \\
\hline Calcium & $\mathrm{cmol}_{\mathrm{c}} \mathrm{dm}^{-3}$ & 1.6 & 0.9 \\
\hline Magnesium & $\mathrm{cmol}_{\mathrm{c}} \mathrm{dm}^{-3}$ & 0.4 & 0.2 \\
\hline Sodium & $\mathrm{cmol}_{\mathrm{C}} \mathrm{dm}^{-3}$ & 0.02 & 0.02 \\
\hline Aluminum & $\mathrm{cmol}_{\mathrm{c}} \mathrm{dm}^{-3}$ & 0.0 & 0.0 \\
\hline Hydrogen & $\mathrm{cmol}_{\mathrm{c}} \mathrm{dm}^{-3}$ & 1.7 & 1.3 \\
\hline CEC $^{*}$ & $\mathrm{cmol}_{\mathrm{c}} \mathrm{dm}^{-3}$ & 3.9 & 2.5 \\
\hline P (Mehlich-1) & $\mathrm{mg} \mathrm{dm}{ }^{-3}$ & 18.0 & 14.0 \\
\hline Organic matter & $\mathrm{g} \mathrm{kg}^{-1}$ & 10.0 & 4.0 \\
\hline Base saturation & $\%$ & 57.0 & 48.0 \\
\hline Clay & $\mathrm{g} \mathrm{kg}^{-1}$ & 60 & 60 \\
\hline Silt & $\mathrm{g} \mathrm{kg}^{-1}$ & 20 & 20 \\
\hline Sand & $\mathrm{g} \mathrm{kg}^{-1}$ & 920 & 920 \\
\hline
\end{tabular}


station of the UFPI/CPCE during the experimental period, are shown in Figure 1.
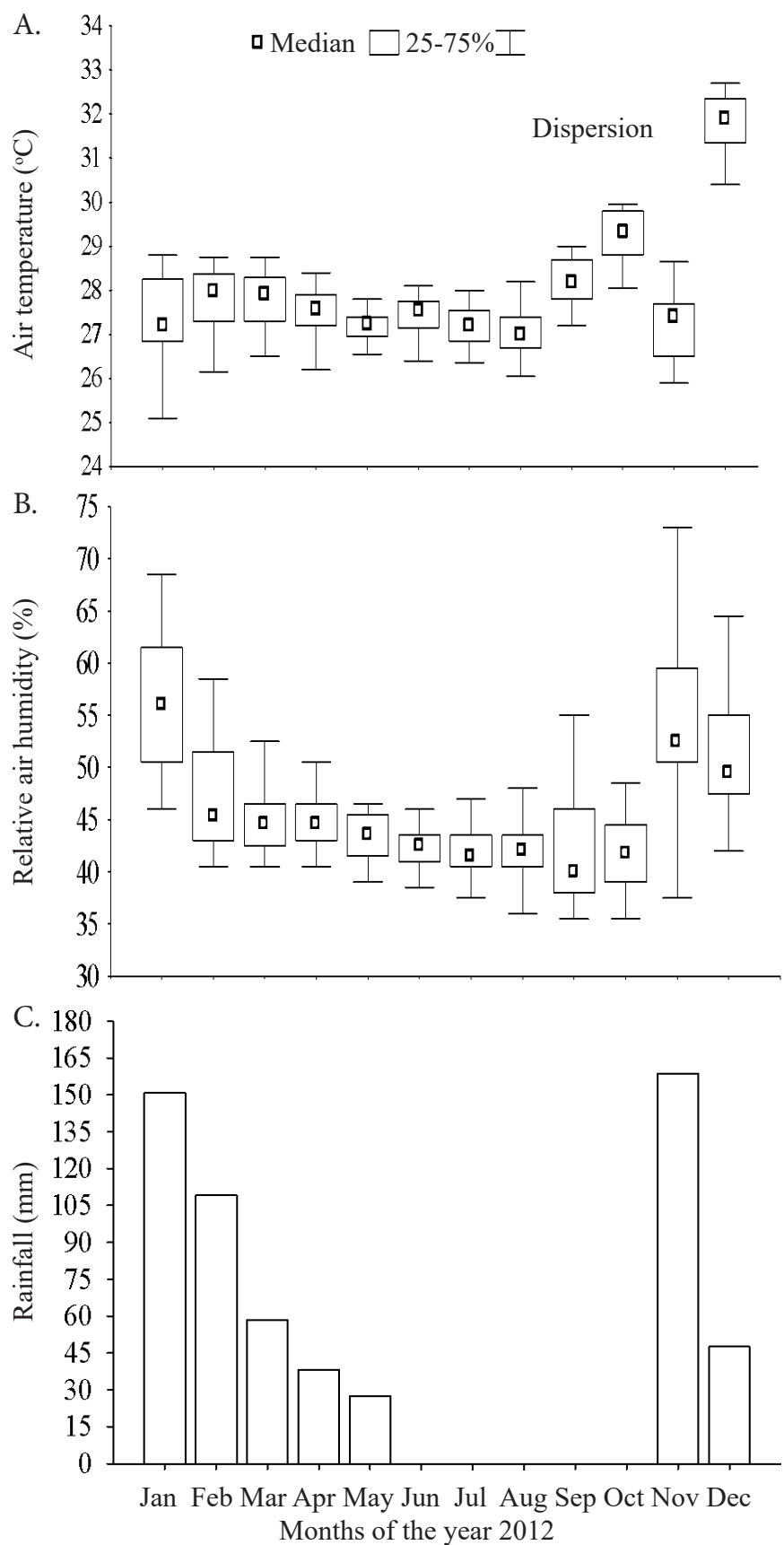

Figure 1. Air temperature $(A)$, relative humidity $(B)$ and rainfall $(C)$ during the experimental perior
Liming was performed 60 days before transplantation, based on the result of the soil chemical analysis for the experimental area, through the application of $1.22 \mathrm{t} \mathrm{ha}^{-1}$ of dolomitic limestone $(\mathrm{RNV}=75 \%)$ in the total area. The pits were opened with dimensions of $40 \times 40 \times 40 \mathrm{~cm}$, where $170 \mathrm{~g}$ of single superphosphate $\left(18 \%\right.$ of $\left.\mathrm{P}_{2} \mathrm{O}_{5}\right)$ were applied according to the recommendations of Costa \& Costa (2007).

Seedlings transplantation was performed using two plants per pit and thinning occurred 120 days after flowering, leaving only the most vigorous hermaphrodite plant, according to Marin (2004).

Plants were irrigated by a drip irrigation system using two emitters per plant with flow rate of $3.74 \mathrm{~L} \mathrm{~h}^{-1}$ each. The applied water depths were daily determined according to the reference evapotranspiration (ETo), obtained from the multiplication of the Class A pan evaporation and the adopted $\mathrm{Kp}$, which was 0.75 . The obtained ETo values were multiplied by the crop coefficient of papaya in its respective development stages, according to Marin (2004). Always when the amount of rain exceeded the evaporation of the pan, irrigation was suspended. Plants were subjected to the cultural practices recommended by Marin (2004).

For the determination of the nutritional status of papaya plants, "F" leaves (leaf base with the first flower fully developed) were collected 120 days after transplantation, when plants were in full flowering (Malavolta et al., 1997), at the laboratory of Plant Science of the UFPI/CPCE. Then, the contents of macronutrients were determined according to the methodology described by Malavolta et al. (1997).

Harvest was performed from October 2012 to February 2013, along with the determination of the production of fruits plant $^{-1}\left(\mathrm{~kg} \mathrm{plant}^{-1}\right)$, considering fruits collected weekly in the maturation stage 3 , when the yellow color covered only 25 to $50 \%$ of the surface of the peel (Marin, 2004). Then, the fruits were selected, counted and weighed on a precision scale $(0.01$ g), for the determination of the mass of fruits per plant.

The data were subjected to analysis of variance in order to identify significant effects between $\mathrm{N}$ sources and doses, by $\mathrm{F}$ test, and comparison of means of $\mathrm{N}$ sources by Tukey test. $\mathrm{N}$ doses were evaluated based on simple polynomial regression analysis, using the programs Assistat and Sigmaplot.

\section{RESUlts AND Discussion}

As observed in Table 2, there was individual effect of $\mathrm{N}$ sources only on leaf contents of $\mathrm{N}$ and $\mathrm{K}$ and on production

Table 2. Summary of analysis of variance and mean eaf contents of nitrogen $(\mathrm{N})$, phosphorus (P), potassium (K), calcium (Ca), magnesium (Mg) and sulfur (S) and production of Formosa papaya cultivated under different doses of coated and conventional urea

\begin{tabular}{|c|c|c|c|c|c|c|c|}
\hline \multirow{2}{*}{ Source of variation } & $\bar{N}$ & $\mathbf{P}$ & K & $\mathrm{Ca}$ & $\mathrm{Mg}$ & $S$ & Production \\
\hline & \multicolumn{7}{|c|}{ Mean square } \\
\hline Source of N (S) & $4.26^{\star \star}$ & $1.50^{\mathrm{ns}}$ & $172.78^{\star \star}$ & $0.06^{\text {ns }}$ & $0.01^{\mathrm{ns}}$ & $0.10^{\text {ns }}$ & $16.68^{\star \star}$ \\
\hline Doses of N (D) & $13.80^{* *}$ & $4.86^{*}$ & $113.84^{* *}$ & $11.11^{* *}$ & $4.69^{*}$ & $3.23^{*}$ & $25.51^{* *}$ \\
\hline Interaction (S x D) & $25.99^{\star \star}$ & $0.95^{\text {ns }}$ & $47.73^{\star \star}$ & $14.60^{\star \star}$ & $1.30^{\text {ns }}$ & $2.72^{\mathrm{ns}}$ & $1.52^{\star \star}$ \\
\hline \multirow[t]{3}{*}{ CV (\%) } & 1.91 & 12.21 & 3.07 & 6.45 & 12.23 & 11.48 & 17.96 \\
\hline & \multicolumn{7}{|c|}{ Mean } \\
\hline & \multicolumn{6}{|c|}{$\mathrm{g} \mathrm{kg}^{-1}$} & $\mathrm{~kg} \mathrm{plant}^{-1}$ \\
\hline Coated urea & $43.67 \mathrm{a}$ & $6.80 \mathrm{a}$ & $35.07 \mathrm{a}$ & $19.87 \mathrm{a}$ & $5.85 \mathrm{a}$ & $4.00 \mathrm{a}$ & $6.19 a$ \\
\hline Conventional urea & $42.57 \mathrm{~b}$ & $6.45 \mathrm{a}$ & $30.40 \mathrm{~b}$ & $19.98 \mathrm{a}$ & $5.85 \mathrm{a}$ & $3.95 \mathrm{a}$ & $4.77 \mathrm{~b}$ \\
\hline LSD & 0.60 & 0.59 & 0.74 & 0.94 & 0.52 & 0.34 & 0.72 \\
\hline
\end{tabular}

CV - Coefficient of variation; LSD - Least significant difference; ns Not significant; **Significant at 0.01 probability level

Means followed by different letters in the columns differ statistically by Tukey test 
A.

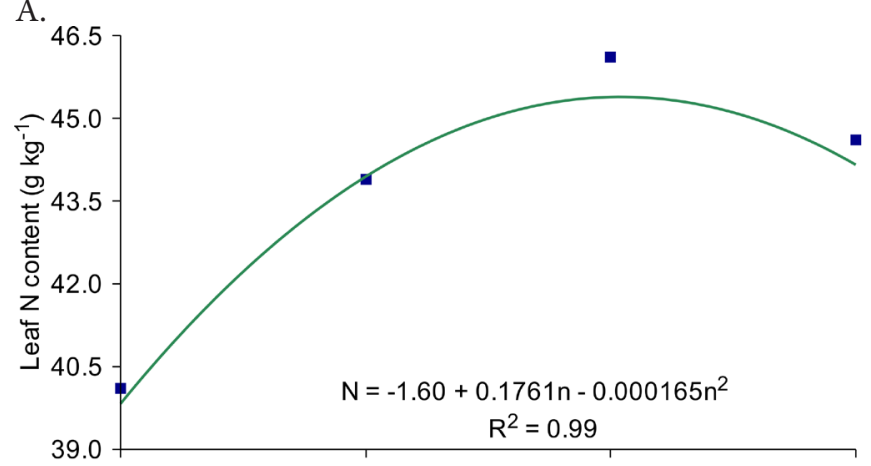

C.

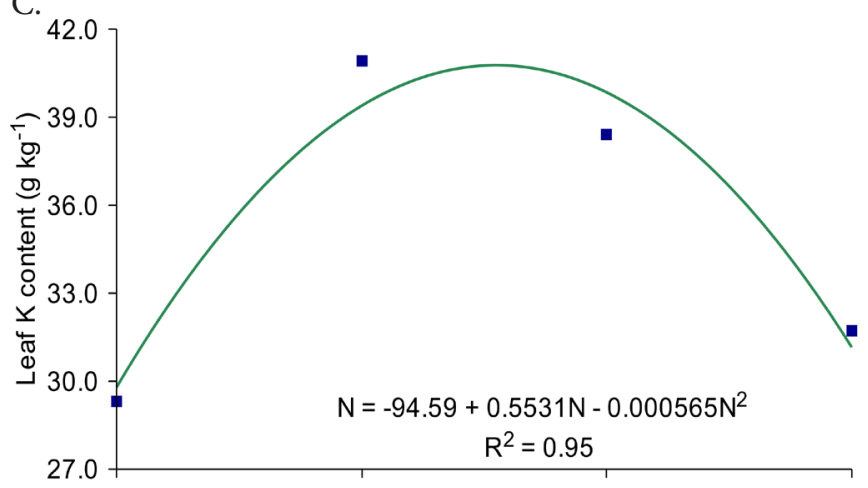

E.

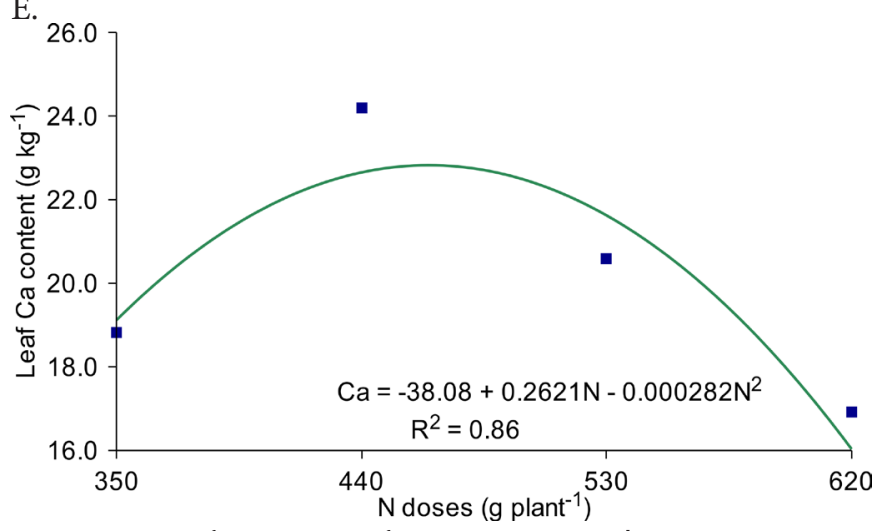

B.

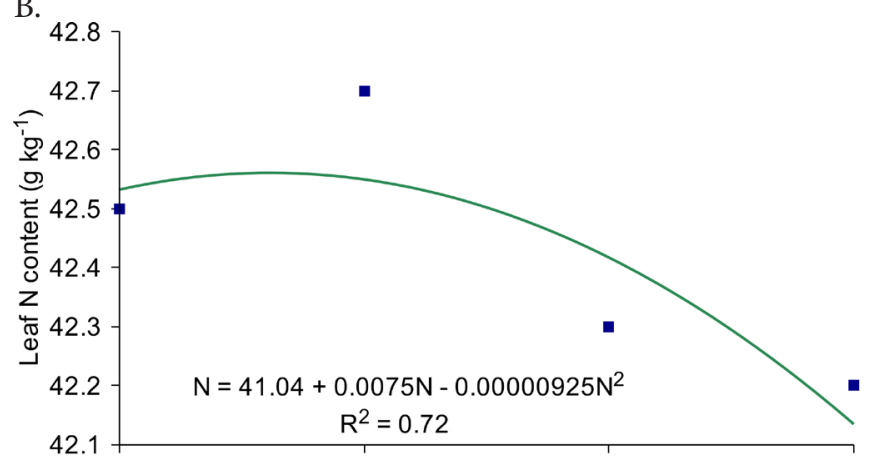

D.

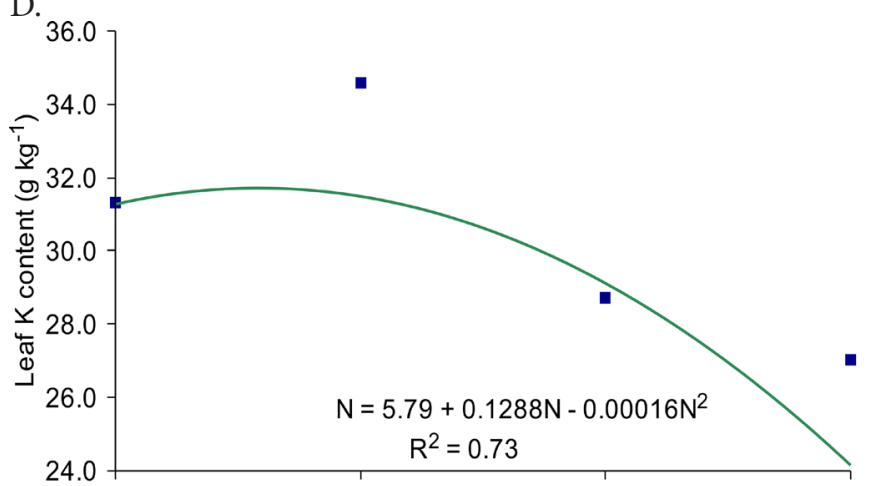

F.

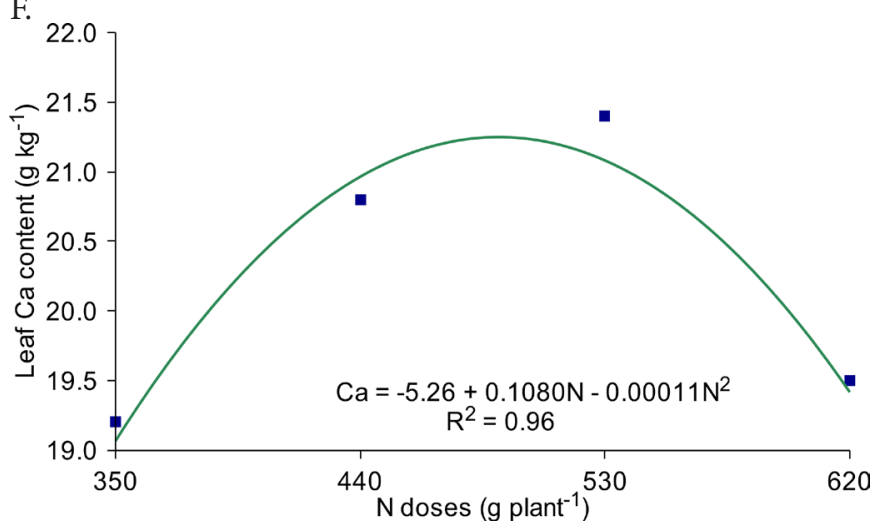

Figure 2. Leaf contents of nitrogen ( $A$ and $B$ ), potassium (C and D) and calcium ( $E$ and $F$ ) of Formosa papaya cultivated under different doses of coated and conventional urea. A, C and E: coated urea fertilization; B, D and F: conventional urea fertilization

$(\mathrm{p}<0.01)$, while $\mathrm{N}$ doses promoted significant differences for the leaf contents of $\mathrm{N}, \mathrm{K}$ and $\mathrm{Ca}$ and production $(\mathrm{p}<0.01)$, and for the contents of $\mathrm{P}, \mathrm{Mg}$ and $\mathrm{S}(\mathrm{p}<0.05)$. For the interaction between the studied sources and doses, there was significant effect on the contents of $\mathrm{N}, \mathrm{K}$ and $\mathrm{Ca}$ at 0.01 probability level.

There was an increment of $2.52 \%$ in $\mathrm{N}$ contents for plants fertilized with polymer-coated urea in comparison to conventional urea (Table 2). The superiority of coated urea occurred because polymer-coated granules have resins that allow long time of solubilization, thus releasing the nutrient, gradually and by diffusion, through the micropores to the soil solution (Hu et al., 2012), with reduction of leaching losses, especially in sandy soils (Osman \& El-Rahman., 2009), as the soil of the experimental area (Table 1). These results agree with those observed for other fruit crops of economic importance, such as peach (Kandil et al., 2010) and guava (Osman \& ElRahman, 2009).

It should be pointed out that the texture of the soil cultivated with papaya, $920 \mathrm{~g} \mathrm{~kg}^{-1}$ of sand (Table 1), favors the efficiency of coated fertilizers, since $\mathrm{N}$ losses through

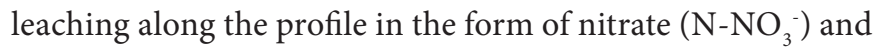
through volatilization of ammonia $\left(\mathrm{N}-\mathrm{NH}_{3}\right)$ are intensified in sandy soils, a common phenomenon in orchards of fruit crops (Barlow et al., 2009). Leaf $\mathrm{N}$ contents were also significantly affected by the $\mathrm{N}$ doses applied to the soil. For the coated fertilizer, the maximum estimated dose of $\mathrm{N}$ was $533.63 \mathrm{~g} \mathrm{plant}^{-1}$, which corresponds to the maximum $\mathrm{N}$ content of $45.38 \mathrm{~g} \mathrm{~kg}^{-1}$ in the leaf dry matter. For the $\mathrm{N}$ contents as a function of the application of conventional urea (Figure 2B), the maximum estimated value was $405.40 \mathrm{~g}$ of N plant ${ }^{-1}$, promoting leaf $\mathrm{N}$ content of $42.56 \mathrm{~g} \mathrm{~kg}^{-1}$.

The lowest leaf $\mathrm{N}$ contents observed with the increment in $\mathrm{N}$ doses from the maximum estimated doses for both sources can be attributed to the $\mathrm{N}$ sufficiency achieved by the plant, according to the range proposed by Malavolta et al. (1997). According to Morgan et al. (2009), at the highest N doses applied, reactions of dissolution with greater increase in the $\mathrm{pH}$ of the site are expected, favoring the formation and, 
consequently, the emission of $\mathrm{N}-\mathrm{NH}_{3}$, decreasing the use of $\mathrm{N}$ applied as mineral fertilizer by papaya plants.

The values of leaf $\mathrm{N}$ contents, from 40.0 to $53.1 \mathrm{~g} \mathrm{~kg}^{-1}$, are consistent with $42.6,44.9$ and $45.0 \mathrm{~g} \mathrm{~kg}^{-1}$ reported by Falcão \& Borges (2006), Almeida et al. (2002) and Campostrini et al. (2001). Malavolta et al. (1997) described the range of 40 to $50 \mathrm{~g} \mathrm{~kg}^{-1}$ as ideal for papaya at flowering. Therefore, the plants cultivated in the present study, regardless of the $\mathrm{N}$ source applied to the soil, had adequate $\mathrm{N}$ supply.

The mean $\mathrm{K}$ content in papaya plants that received coated urea as $\mathrm{N}$ source was $13.32 \%$ higher compared with plants cultivated under conventional urea (Table 2). $\mathrm{N}$ application in the form of urea promoted higher $\mathrm{K}$ contents in the leaves, probably because this source has part of the $\mathrm{N}$ in the nitric form, which may have favored the absorption of the cation $\mathrm{K}^{+}$, as reported by Marschner (2005). The increment in leaf $\mathrm{K}$ contents with the application of polymer-coated $\mathrm{N}$ fertilizer was also observed by Kandil et al. (2010), with superiority of $9.14 \%$ in comparison to the application of conventional urea.

The $\mathrm{K}$ contents of $35.07 \mathrm{~g} \mathrm{~kg}^{-1}$ observed in this study are higher than $27.30 \mathrm{~g} \mathrm{~kg}^{-1}$ of $\mathrm{K}$ in the leaves of 'Baixinho de Santa Amália’ papaya at 120 days after transplantation and higher than the range of 25.0 to $30.0 \mathrm{~g} \mathrm{~kg}^{-1}$ of $\mathrm{K}$, considered as adequate to supply the plants with $\mathrm{K}$, according to Malavolta et al. (1997), although no visual symptom of excess was identified in the plants.

The increment in the absorption of $\mathrm{N}$ and $\mathrm{K}$ due to the application of polymer-coated fertilizers may contribute to the reduction of the losses of these nutrients through leaching, thus decreasing the effects of environmental pollution of nitrate, which is easily leached through the drainage of rainwater or irrigation, especially in sandy soils (Luna et al., 2013).

$\mathrm{K}$ contents increased until 40.77 and $31.71 \mathrm{~g} \mathrm{~kg}^{-1}$ (Figures $2 \mathrm{C}$ and $2 \mathrm{D})$ referring to the maximum estimated doses of 489.47 and $402.31 \mathrm{~g} \mathrm{plant}^{-1}$ of $\mathrm{N}$ for the sources coated urea and conventional urea, respectively, with reductions in leaf $\mathrm{K}$ contents with the application of doses higher than the respective maximum estimated doses. Additionally, for the maximum estimated $\mathrm{K}$ doses, the application of coated urea resulted in an increment of $22.22 \%$ in leaf $\mathrm{N}$ contents, compared with conventional urea, which represents increase of $9.06 \mathrm{~g} \mathrm{~kg}^{-1}$ in leaf K content. Santos et al. (2014), evaluating $\mathrm{N}$ doses at different planting spacings of Formosa papaya, cv. Caliman, also observed increments in $\mathrm{K}$ contents with the increase in $\mathrm{N}$ fertilization.

The increase in leaf $\mathrm{K}$ contents as a function of $\mathrm{N}$ application can be explained by the fact that $\mathrm{N}$ is transported to plant shoots in the form of potassium nitrate $\left(\mathrm{KNO}_{3}\right)$ (Marschner, 2005) and the monthly application of K contributed to its ideal supply during crop development.

As to leaf $\mathrm{Ca}$ contents (Figure $2 \mathrm{E}$ ), the maximum value for coated urea was $22.82 \mathrm{~g} \mathrm{~kg}^{-1}$, promoted by the $\mathrm{N}$ dose of 464.04 g plant $^{-1}$, while for conventional urea (Figure $2 \mathrm{~F}$ ), the maximum $\mathrm{N}$ dose was $490.91 \mathrm{~g}$ plant $^{-1}$, with leaf Ca content of $21.24 \mathrm{~g} \mathrm{~kg}^{-1}$. These values are within the range adopted as sufficient for papaya (Malavolta et al., 1997) and are similar to $22.82 \mathrm{~g} \mathrm{~kg}^{-1}$, obtained by Falcão \& Borges (2006).

For $\mathrm{P}$ contents in the shoot dry matter of Formosa papaya (Figure $3 \mathrm{~A}$ ), the increment in $\mathrm{N}$ doses increased $\mathrm{P}$ contents

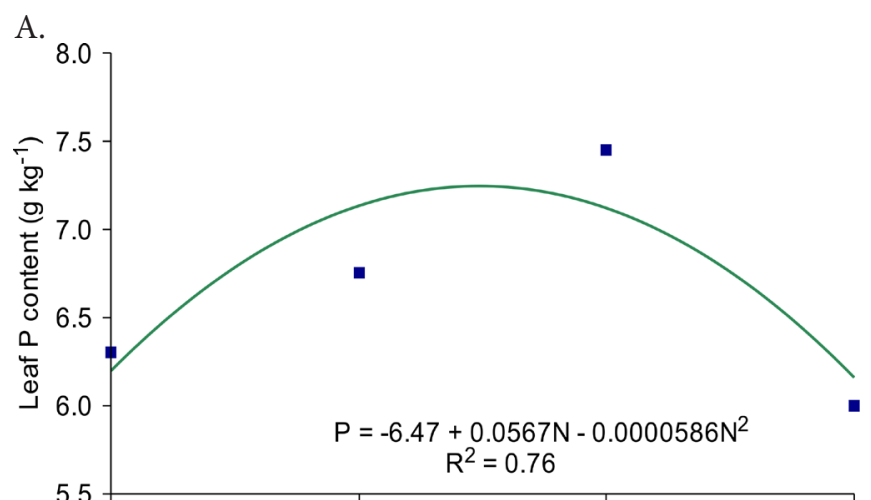

B.

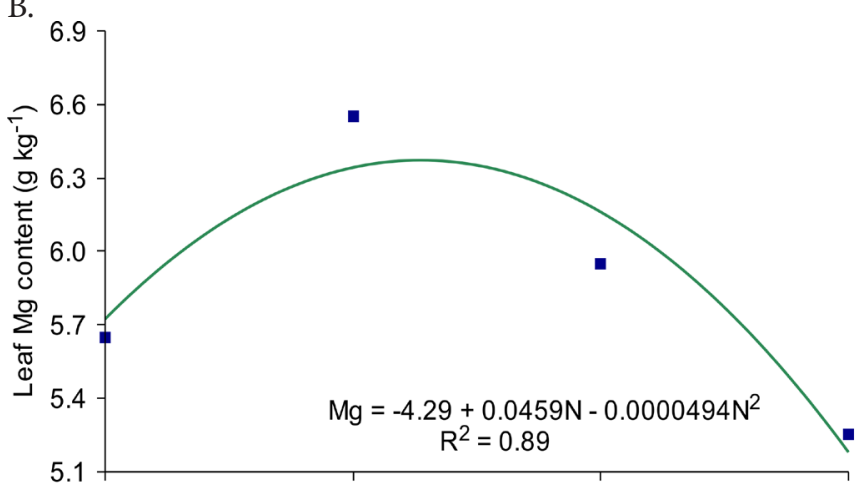

C.

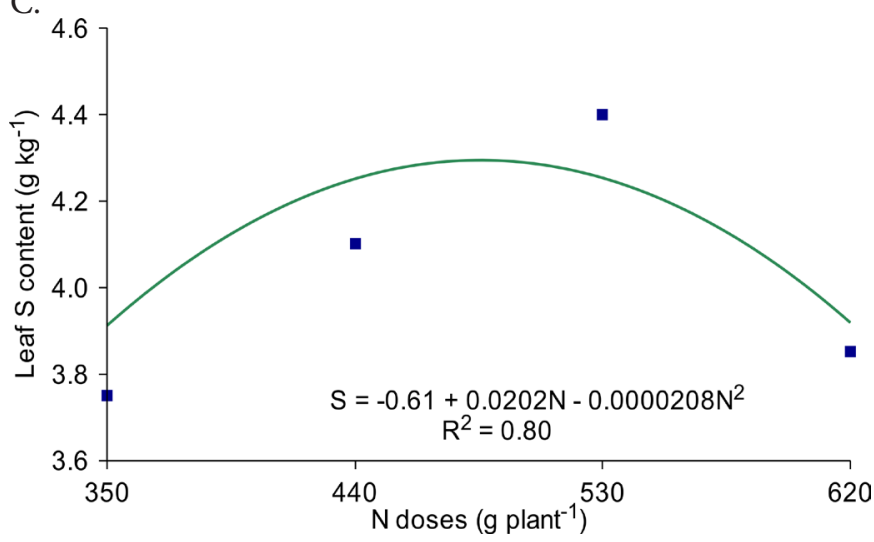

Figure 3. Leaf contents of phosphorus (A), magnesium (B) and sulfur (C) of Formosa papaya as a function of different doses of top-dressing nitrogen fertilization

until the maximum estimated dose of $483.78 \mathrm{~g}$ of $\mathrm{N}_{\text {plant }}{ }^{-1}$, corresponding to the maximum content of $7.25 \mathrm{~g} \mathrm{~kg}^{-1}$ of $\mathrm{P}$, which are within the range considered as sufficient for papaya (Malavolta et al., 1997) and higher than the range of 5.0 to 7.0 $\mathrm{g} \mathrm{kg}^{-1}$ of P, recommended by Costa \& Costa (2007) for plants with age from 120 to 140 days after transplantation.

The increment of leaf $\mathrm{P}$ contents with the increase in $\mathrm{N}$ doses in the soil was probably due to the synergism between $\mathrm{N}$ and $\mathrm{P}$ contents in the plants (Marschner, 2005), since $\mathrm{N}$ fertilization has a positive effect on leaf $\mathrm{P}$ contents.

Regardless of the studied N source, Mg contents (Figure $3 \mathrm{~B}$ ) in the leaf dry matter of Formosa papaya increased with the increment in $\mathrm{N}$ dose until the maximum estimated value of $464.57 \mathrm{~g} \mathrm{plant}^{-1}$ of $\mathrm{N}$, which promoted $\mathrm{Mg}$ content of $6.37 \mathrm{~g} \mathrm{~kg}^{-1}$. These maximum results are lower than $10.0 \mathrm{~g} \mathrm{~kg}^{-1}$, described by Malavolta et al. (1997) as sufficient for the nutrition of papaya plants. The fact that leaf $\mathrm{Mg}$ contents are below the range considered as ideal for the crop and, in contrast, the 
ideal $\mathrm{K}$ contents are above it, is related to the inhibition of $\mathrm{Mg}^{2+}$ absorption caused by the high $\mathrm{K}^{+}$contents (Marschner, 2005).

Sulfer $(\mathrm{S})$ contents in the leaf dry matter of Formosa papaya (Figure 3C) also increased as a function of $\mathrm{N}$ doses applied to the soil, and the maximum estimated dose was 485.58 g plant $^{-1}$, which corresponds to the $\mathrm{S}$ content of $4.29 \mathrm{~g} \mathrm{~kg}^{-1}$. Therefore, it is superior to the maximum mean of $3.86 \mathrm{~g} \mathrm{~kg}^{-1}$ of $\mathrm{S}$, reported by Santos et al. (2014), who evaluated the nutritional status of Formosa papaya (hybrid Caliman 01) as a function of $\mathrm{N}$ fertilization. On the other hand, the maximum $S$ values were higher than that observed by Santana et al. (2004) in papaya plants from the 'Solo' group, cultivated under the application of conventional fertilizer.

Comparing the $S$ values shown in Figure $3 \mathrm{C}$ with $6.0 \mathrm{~g} \mathrm{~kg}^{-1}$ of S, considered by Malavolta et al. (1997) as sufficient for the crop, the plants were deficient in S. Although the P source used in the experiment was single superphosphate (10\% of S), it was not enough for an adequate supply of $S$ and, probably, the balance between $\mathrm{N}$ supply through urea application and $\mathrm{S}$ through $\mathrm{P}$ fertilization was not adequate as well, thus causing an apparent $\mathrm{N}$ accumulation in the plant (Table 2). This situation was also evidenced by Jamal et al. (2010) and Santos et al. (2014), who observed that significant relationships between $\mathrm{N}$ and $\mathrm{S}$ in the soil, caused by higher doses of $\mathrm{N}$ fertilization, result in lower $\mathrm{S}$ availability.

The mean production of fruits per plant, for both $\mathrm{N}$ sources, increased with the increments in $\mathrm{N}$ doses, and the coated fertilizer (Figure 4) was superior to the conventional fertilizer at all of the studied $\mathrm{N}$ doses. Thus, coated urea promoted maximum estimated production of $8.08 \mathrm{~kg} \mathrm{plant}^{-1}$, corresponding to the $\mathrm{N}$ dose of $525 \mathrm{~g} \mathrm{plant}^{-1}$, while the maximum production promoted by conventional urea fertilization was only $6.42 \mathrm{~kg} \mathrm{plant}^{-1}$ for a maximum $\mathrm{N}$ dose of $500.9 \mathrm{~g} \mathrm{plant}^{-1}$.

The increment in fruit production promoted by the application of coated urea is due to the fact that polymer-coated fertilizers reduce $\mathrm{N}$ losses through leaching and volatilization, showing greater efficiency in the yield of some crops (Osman \& El-Rahman, 2009). Additionally, Brito Neto et al. (2011) claim that the gradual supply of $\mathrm{N}$, with better spatial distribution in the soil during the productive stage, is of great importance for the papaya crop, favoring the synchronization between the supply of this nutrient and the physiological demand of the plant, such as the formation of flowers and fruits.

The highest estimated production of Formosa papaya is consistent with the value of $8.0 \mathrm{~kg} \mathrm{plant}^{-1}$, reported by Brito

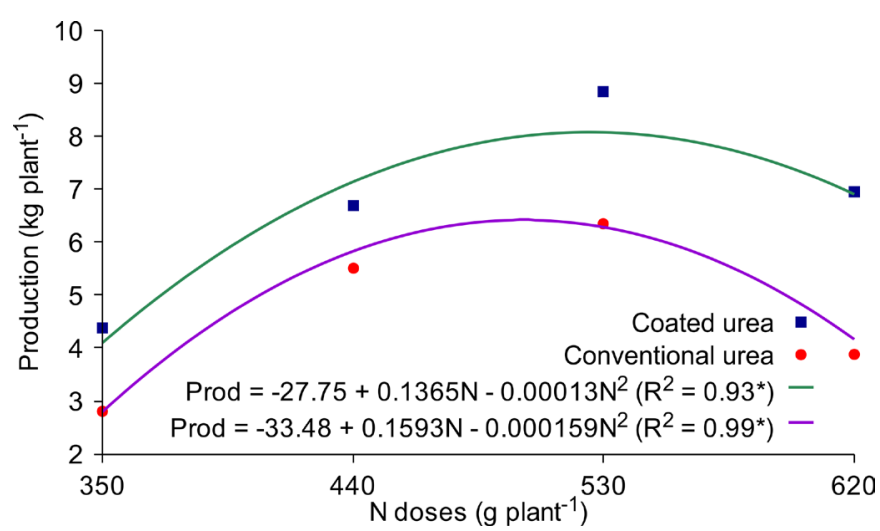

Figure 4. Fruit production of Formosa papaya cultivated under different doses of coated and conventional urea
Neto et al. (2011) in a study with 'Sunrise Solo' papaya as a function of $\mathrm{N}$ doses, and lower than $17.34 \mathrm{~kg}_{\text {plant }}{ }^{-1}$, reported by Souza et al. (2007) for Formosa papaya, cv. Tainung 01, fertigated with different combinations of $\mathrm{N}$ fertilization. The lower production may be attributed to the short period of harvest, with duration of 120 days, mainly associated with the low relative air humidity, according to the data recorded during the cultivation period (Figure 1B), because Reis \& Campostrini (2008) claim that the mean relative air humidity recommended for the flowering stage of papaya is 60 to $85 \%$. Values below this range promote high rates of flower abortion, which was observed during the flowering of papaya plants.

\section{Conclusions}

1. N sources and doses improve the nutritional status with macronutrients and the production of Formosa papaya, hybrid Caliman 01.

2. The increase in $\mathrm{N}$ doses for the coated source applied as top-dressing promotes higher $\mathrm{N}$ contents and fruit production, compared with conventional urea.

3. Based on the contents of macronutrients considered as adequate for the nutrition of the crop, associated with the maximum fruit production, the supply of $525 \mathrm{~g} \mathrm{plant}^{-1}$ of $\mathrm{N}$ is recommended in the form of coated urea.

\section{ACKNOWLeDgments}

To Banco do Nordeste, for the financial support to the research.

\section{Literature Cited}

Almeida, F. T.; Bernardo, S. Marinho, C. S.; Marin, S. L. D.; Sousa, E. F. Teores de nutrientes do mamoeiro "Improved Sunrise Solo $72 / 12$ " sob diferentes lâminas de irrigação no norte fluminense. Revista Brasileira de Fruticultura, v.24, p.547-551, 2002. http:// dx.doi.org/10.1590/S0100-29452002000200053

Azevedo, E. B.; Marinho, C. S.; Muniz, R. A.; Carvalho, A. J. C. Substratos fertilizados com ureia revestida e o crescimento e estado nutricional da muda de citros. Acta Scientiarum. Agronomy, v.31, p.129-137, 2009. http://dx.doi.org/10.4025/actasciagron.v31i1.6639

Barlow, K.; Bond, W.; Holzapfel, B.; Smith, J. Hotton, R. Nitrogen concentrations in soil solution and surface run-off on irrigated vineyards in Australian. Australian Journal of Grape and Wine Research, v.15, p.131-143, 2009. http://dx.doi.org/10.1111/j.17550238.2008.00042.x

Brito Neto, J. F.; Pereira, W. E.; Cavalcante, L. F.; Araújo, R. C.; Lacerda, J. S. Produtividade e qualidade de frutos de mamoeiro 'sunrise solo' em função de doses de nitrogênio e boro. Semina: Ciências Agrárias, v.32, p.69-80, 2011. http://dx.doi.org/10.5433/1679-0359.2011v32n1p69

Campostrini, E.; Marinho, C. S.; Yamanyshi, O. K.; Matos, A. T. Teores foliares de nutrientes e produção do mamoeiro cultivado em duas propriedades efetivas. Revista Brasileira de Fruticultura, v.23, p.101-104, 2001.

Costa, A. N. da; Costa, A. de F. S da. Diagnóstico e recomendação de adubação para o mamoeiro. In: Martins, D. dos S.; Costa, A. N.; Costa, A. de F. S. da C. (ed.). Manejo, qualidade e mercado do mamão. Vitória: Incaper, 2007. p.15-26. 
EMBRAPA - Empresa Brasileira de Pesquisa Agropecuária Sistema brasileiro de classificação de solos. Brasília: Embrapa Produção de Informação, 2013. 353p.

Falcão, N. P. S.; Borges, L. F. Efeito da fertilidade de terra preta de índio da Amazônia central no estado nutricional e na produtividade do mamão Havaí (Carica papaya L.). Acta Amazônica, v.36, p.400406, 2006. http://dx.doi.org/10.1590/S0044-59672006000400001

Fontes, R. V.; Viana, A. P.: Pereira, M. G.; Oliveira, J. G.; Silva, D. M.; Broetto, S. G.; Silva, M. M. Diferentes espaçamentos de plantio e níveis de adubação sobre a atividade da redutase do nitrato em folhas do híbrido de mamoeiro UENF/CALIMAN-01. Revista Brasileira de Fruticultura, v.32, p.1138-1145, 2010. http://dx.doi. org/10.1590/S0100-29452010000400023

Hu, H.; Ning, T.; Li, Z.; Han, H.; Zhang, Z.; Qin, S.; Zheng, Y. Coupling effects of urea types and subsoiling on nitrogen-water use and yield of different varieties of maize in northern China. Fields Crop Research, v.142, p.84-84, 2012. http://dx.doi.org/10.1016/j.fcr.2012.12.001

Jamal, A.; Moon, Y. S.; Abdin, M. Z. Enzyme activity assessment of peanut (Arachis hypogea) under slow-release sulphur fertilization. Australian Journal of Crop Science, v.4, p.169-174, 2010.

Kandil, E. A., Fawzi, M. I. F. M.; Shahin F. M. The effect of some slow release nitrogen fertilizers on growth, nutrient status and fruiting of "Mit Ghamr" peach trees. Journal of American Science, v.6, p.195-201, 2010.

Lorenzini, F.; Ceretta, C. A.; Girotto, E.; Cerini, J. B.; Lourenzi, C. R.; Conti, L. Trindade, M. M.; Melo, G. W.; Brunetto, G. Lixiviação e volatilização de nitrogênio em um Argissolo cultivado com videira submetida à adubação nitrogenada. Ciência Rural, v.42, p.11731179, 2012. http://dx.doi.org/10.1590/S0103-84782012005000038

Luna, N. R. de S.; Andrade, E. M.; Crisóstomo, L. A.; Meireles, A. C. M.; Aquino, D. N. Dinâmica do nitrato e cloreto no solo e a qualidade das águas subterrâneas do distrito de irrigação Baixo Acaraú, CE. Revista Agroambiente, v.7, p.53-62, 2013. http:// dx.doi.org/10.18227/1982-8470ragro.v7i1.1042
Malavolta, E.; Vitti, G. C.; Oliveira, S. A. Avaliação do estado nutricional das plantas: princípios e aplicações. 2.ed., Piracicaba: Potafós, 1997. 28p.

Marin, S. L. D. Mamão papaya: Produção, pós-colheita e mercado. 2.ed., Fortaleza: Instituto Frutal, 2004. 82p.

Marschner, H. Mineral nutrition of higher plants. 6.ed. London: Academic Press, 2005. 889p.

Morgan, K. T.; Cushman, K. E.; Sato, S. Release mechanisms for slow and controlled release fertilizers and strategies for their use in vegetable production. HortTechnology, v.19, p.10-12, 2009.

Osman, S. M.; El-Rahman, A. E. M. Effect of slow release nitrogen fertilization on growth and fruiting of guava under mid Sinai conditions. Australian Journal of Basic and Applied Sciences, v.3, p.4366-4375, 2009.

Reis, F. O.; Campostrini, E. Trocas gasosas e eficiência fotoquímica potencial em mamoeiro do grupo 'Formosa' cultivado em condição de campo. Bragantia, v.67, p.815-822, 2008. http://dx.doi. org/10.1590/S0006-87052008000400002

Santana, J. das G.; Mozena, W. L.; Cunha, P. P.; Fernandes, E. P.; Vaz, E. R. R.; Paula, C. M. de. Níveis de suficiência para análise foliar de mamão (Carica papaya L. cv. Sunrise Solo), no Estado de Goiás, obtidos por diferentes procedimentos de cálculo dos índices DRIS. In: Reunião Brasileira de Fertilidade do Solo e Nutrição de Plantas, 26, 2004, Lages. Anais... Lages: SBCS, 2004. CD Rom. Santos, E. M.; Cavalcante, İ. H. L.; Silva Júnior, G. B.; Albano; F. G.; Lima, F. N.; Sousa, A. M.; Cavalcante, L. F. Estado nutricional do mamoeiro Formosa (cv. Caliman 01) em função de adubação com NK e espaçamento de plantio. Comunicata Scientiae, v.5, p.229-240, 2014.

Souza, T. V.; Paz, V. P. S.; Coelho, E. F.; Pereira, F. A. C.; Ledo, C. A. S. Crescimento e produtividade do mamoeiro fertirrigado com diferentes combinações de fontes nitrogenadas. Irriga, v.12, p.563-574, 2007. 